\title{
Pathogenicity of Helicotylenchus indicus Siddiqi, 1963 on papaya and impact of some bio-organic materials
}

\author{
Shimaa F. DIAB ${ }^{1}$, Ahlam M. EL-GHONIMY ${ }^{2}$ and Hosny H. KESBA ${ }^{1,3}$ \\ Received April 02, 2019; accepted May 24, 2019. \\ Delo je prispelo 02. aprila 2019, sprejeto 24. maja 2019.
}

Pathogenicity of Helicotylenchus indicus Siddiqi, 1963 on papaya and impact of some bio-organic materials

Abstract: Two pot experiments were conducted to determine the growth response of papaya, 'Solo' and H. indicus reproduction in relation to different levels of nematode inocula (0, 1000, 2000, 4000, 8000 and 12000 nematode/pot) and impact of some commercial products, e.g. Bio Tonic ${ }^{\circ}$, Hundz Soil', Nemakey-N" ${ }^{m}$, Nemastop and Nubtea on nematode management, plant growth and NPK contents. As increase nematode density to 4000 and up to 12000 nematode/pot, significant reductions in plant length, fresh or dry mass were detected. The highest reduction in plant growth was achieved by density of 12000 nematode/pot. Most inoculation levels reduced plant contents of $\mathrm{N}$ and $\mathrm{K}$ regardless to nematode density. Tremendous increase in plant content of $\mathrm{P}$ was obtained by 4000 and 12000 nematode/pot. The nematode build up was decreased by increasing the nematode density. All treatments significantly improved the plant criteria. Significant increase of shoot parameters was obvious in Nubtea treatment. Nemastop had less value of shoot parameters. Negative response was recorded in $\mathrm{P}$ content in all treatments. There were no significant differences among treatments in plant content of $\mathrm{N}$ except Nubtea treatment. The least value of $\mathrm{K}$ was found in Nemastop treatment. The Nemakey- $\mathrm{N}^{\mathrm{m}}$ overwhelmed all treatments in reducing all nematode criteria.

Key words: papaya; Helicotylenchus; population density; inoculum level; control
Patogenost ogorčice Helicotylenchus indicus Siddiqi, 1963 za papajo in vpliv nekaterih bio-organskih pripravkov

Izvleček: Izvedena sta bila dva lončna poskusa za določitev rastnega odziva papaje 'Solo' in razmnoževanja ogorčice $H$. indicus glede na njeno različno število v inokulih $(0,1000,2000$, 4000, 8000 in 12000 ogorčic na lonec) in vpliv nekaterih komercialnih pripravkov kot so Bio Tonic', Hundz Soil', Nemakey$\mathrm{N}^{\prime \prime}$, Nemastop in Nubtea na upravljanje z ogorčicami, na rast rastlin in njihovo vsebnost NPK. Povečanje gostote ogorčic na 4000 do 12000 ogorčic na lonec je značilno zmanjšalo dolžino rastlin, njihovo svežo in suho maso. Največje zmanjšanje rasti rastlin je bilo doseženo pri gostoti 12000 ogorčic na lonec. Večina inokulov je zmanjšala vsebnost $\mathrm{N}$ in $\mathrm{K}$ ne glede na gostoto ogorčic. Veliko povečanje v vsebnosti $\mathrm{P} v$ rastlinah je bilo doseženo pri gostotah 4000 do 12000 ogorčic na lonec. Dozorelost ogorčic se je zmanjševala s povečevanjem njihove gostote. Vsa obravnavanja s pripravki so značilno izboljšala merjene rastlinske parametre. Značilno povečanje parametrov poganjka je bilo doseženo s pripravkom Nubtea', pripravek Nemastop ${ }^{\circ}$ je imel nanje manjši učinek. V vsebnosti P so imela obravnavanja $\mathrm{Z}$ vsemi pripravki negativni učinek. $\mathrm{V}$ vsebnosti $\mathrm{N}$ pri obravnavanjih z različnim pripravki ni bilo značilnih razlik, razen pri obravnavanju s pripravkom Nubtea ${ }^{\circ}$ Najmanjša vsebnost K je bila izmerjena pri obravnavanju s pripravkom Nemastop: Pripravek Nemakey-N ${ }^{\text {" }}$ je imel pri vseh obravnavanjih največji učinek na zmanjševanje števila ogorčic.

Ključne besede: papaja; Helicotylenchus; populacijska gostota; število ogorčic v inokulumu; kontrola

1 Cairo University, Faculty of Agriculture, Zoology and Agricultural Nematology Department, Giza 12613, Egypt

2 Nematology Unit, Plant Protection Department, Desert Research Center, Cairo 11753, Egypt

3 Corresponding author, e-mail: hosny.hosny@agr.cu.edu.eg 


\section{INTRODUCTION}

Members of the spiral nematode belonging to Helicotylenchus are either ecto or semiendo-parasitic nematodes. They may occur in very high numbers feeding upon roots of diverse plants, and may be abundant in soil surrounding host roots. Species of such nematode are globally spread, spanning various climates, and associated with the roots of diverse crops of agricultural importance (Firoza and Maqbool, 1995; Marais, 2001; Khan et al., 2007 and Schreck Reis et al., 2008; Rashid and Azad, 2013 and Uzma et al., 2015).

Pathological injuries caused by the spiral nematode species to plants have been studied on Cenchrus ciliaris L. (Jain, 1981), on guava (Willers and Grech, 1986), on chickpea (Sartaj et al., 1999), on carnation (Khanna and Jyot, 2002), on white clover (Zahid et al., 2002), on banana (Moens et al., 2006) and on Celosia cristata L. (Rashid and Azad, 2013). They found that damage was directly proportional to their population densities in soil and their reproduction potentials on the plant. Also, they stated that threshold density may vary according to the nematode species, plant variety and environment.

Papaya (Carica papaya L.) is one of the most important fruits cultivated throughout the world, is typically grown in tropical and subtropical regions, with fast and frequent production (Teixeira da Silva et al., 2007). Lately, it has been cultivated in Egypt in both old and new reclaimed lands, with an average area of 120 Feddans which produced $872000 \mathrm{~kg}$ of papaya fruits during the year 2013 (MALR, 2014).

Growing papaya plants with organic materials as soil amendment for control of plant parasitic nematodes has been reported by many researchers (Zhang and Zhang, 2009, Farahat et al., 2010 \& 2012 and Rashad et al., 2011). For instance, garlic - as a botanical material - possesses nematotoxic activity (Al-Sayed et al., 2007 and Ahmed and Siddiqui, 2009), humic acid - as a plant fertilizer - suppresses nematode activity (Kesba and Al-Shalaby, 2008 and Kesba, 2010). Moreover, NPK fertilizers could minimize nematode population, improve host tolerance and crop performance (Sinha and Neog, 2003 and Kheir et al., 2009).

Therefore, the present investigation was undertaken to study papaya growth response and $H$. indicus reproduction in relation to different levels of nematode inocula; and impact of some commercial organic products on nematode control, plant growth and NPK contents under greenhouse conditions.

\section{MATERIALS AND METHODS}

\subsection{SOURCE OF NEMATODE INOCULA}

Pure culture of H. indicus (Siddiqi, 1963) was obtained from an isolate belong to the Nematology Division, Zoology and Agricultural Nematology Department, Faculty of Agriculture, Cairo University and propagated on Italian cypress, Cupressus macrocarpa Hartw.plants.

\subsection{GREENHOUSE EXPERIMENT}

Six different levels of $H$. indicus were used to inoculate papaya, C. papaya 'Solo.' The nematode inocula were used at the rate of approximately 0, 1000, 2000, 4000, 8000 and 12000 infective stages per plant. Each inoculum level was introduced to 6 seedlings of papaya grown separately in $25 \mathrm{~cm}$ diameter clay pots filled with steam sterilized loamy sand soil $(1: 1, \mathrm{v} / \mathrm{v})$. Water nematode suspension of each inoculum level was pipetted into 4 holes in the soil around the root system of each seedling. The uninoculated pots were kept to serve as a check treatment. Pots of all treatments were randomly arranged in a greenhouse and horticulturally treated the same.

For testing the effect of commercial products on the nematode development and papaya growth, the following materials were used:

- Bio Tonic (powder, organic matter $29.5 \%, \mathrm{~N}$ $1.3 \%, \mathrm{pH} 7.2)$.

- Hundz Soil (powder, imported from USA by some Egyptian companies, contains growth media of recycled agricultural material which has a density of $230 \mathrm{~kg} \mathrm{~m}^{-3}$. It has dry compressed granules that vary in diameter from $1.0 \mathrm{~mm}$ to $1.5 \mathrm{~mm}$ with the same physical characteristics and chemical composition as conventional soil, http://www.hundzsoil.com).

- Nemakey-N" (liquid, organic matter $25 \%, \mathrm{~N}$ $15 \%, \mathrm{pH} 3$ )

- Nemastop (a suspension of garlic extract, $600 \mathrm{~g}$ ground garlic cloves/liter water).

- Nubtea (powder, organic matter 30.9 \%, N $1.03 \%, \mathrm{pH} 8.7)$.

Doses used at the rates $5 \mathrm{~g}$ or $\mathrm{ml}+5 \mathrm{~g}$ or $\mathrm{ml}$ (one month interval) on the spiral nematode development and reproduction. Six seedlings were used for each treatment and inoculated with 4000 infective stages of $\mathrm{H}$. indicus/pot. One week after inoculation, all materials were applied as soil additives and uninoculated-untreated and inoculated-untreated pots were kept to serve as check treatments. All pots were arranged in a fully randomized design on a clean bench in greenhouse at $32 \pm 5^{\circ} \mathrm{C}$ receiving similar horticultural treatments.

Six months after inoculation, the plants were harvested and data on plant growth was recorded. The nem- 
atode populations were extracted from soil by means of sieving technique (Hooper et al., 2005) and counted with the aid of a stereoscopic microscope and a Hawksley counting slide. The nematode stages on the roots were counted.

\subsection{PLANT CHEMICAL ANALYSIS}

Sub-samples ( $1 \mathrm{~g}$ each) of the dry whole plant from each treatment were analyzed at Central Chemistry Lab., Faculty of Agriculture, Cairo University for N, P and K contents by standard methods of the Association of Official Analytical Chemists (Anon., 1990).

\subsection{STATISTICAL ANALYSIS}

Data were compared by Duncan's Multiple Range Test (DMRT) at the $5 \%$ level of probability using MSTAT version 4 (1987).

\section{RESULTS}

Data in Table 1 reveal that all inoculation levels achieved significant decrease in papaya length, fresh and dry mass as compared with the uninoculated check plants. By imposing stress of $H$. indicus through increasing the nematode inoculum density to 4000 and up to 12000 infective stages/pot, significant reductions either in plant length, fresh or dry mass were detected. Statistically, insignificant differences were observed among inoculation levels. However, the highest plant growth reductions were achieved by nematode density 12000 infective stages/pot. Therefore, by increasing the nematode inocula, reductions in plant criteria were obviously increased.

Although, most inoculation levels did reduce the plant contents of $\mathrm{N}$ and $\mathrm{K}$, no obvious correlation was observed between inoculation level and both elements. On the other hand, tremendous increase in plant content of $\mathrm{P}$ was obtained by 4000 and 12000 infective stages/pot (Table 2).

With regard to nematode reproductivity, data in Table 3 indicate that with increasing the nematode initial density up to 12000 infective stages/pot significant increases in numbers of the nematode on roots, in soil and consequently in the nematode final population were obtained. Evidently, the highest values were achieved by 1000 infective stages/pot in such criteria. The nematode build up was decreased by increasing the nematode density. The nematode failed to fold at the highest inoculum level. Potentials of Bio Tonic, Hundz Soil', Nemakey-N", Nemastop and Nubtea used in $5 \mathrm{~g}$ or $\mathrm{ml}+5 \mathrm{~g}$ or $\mathrm{ml}$ (one month interval) on papaya plant growth are presented in Table 4. Data indicate that all treatments succeeded significantly in improving the plant biomass as measured by plant length, fresh and dry mass. The highest significant increase of plant parameters was obvious in Nemakey- $\mathrm{N}^{\text {" }}$ treatment. In contrast, Nemastop treatment had lesser values of length and fresh weight parameters than those of the other treatments.

Unexpectedly, the quantitative chemical analysis of NPK in papaya plants showed contradictory results. For instance, negative response in phosphorus content was noticed in all treatments (Table 5). The least percentage value of phosphorus decrease was found in Nubtea treatment $(-42.6 \%)$. Contrarily, nitrogen content was insignificantly increased in most treatments, except that of Nubtea which achieved $26.7 \%$ increase. Supereminent increase in plant potassium content was achieved by all tested materials with significant differences among treatments.

Data on the efficacy of the organic materials presented in Table 6 indicate that most of which were significantly effective in reducing nematode numbers on root, in soil, final population and subsequent rates of build

Table 1: Influence of different inoculum levels of $H$. indicus on papaya growth

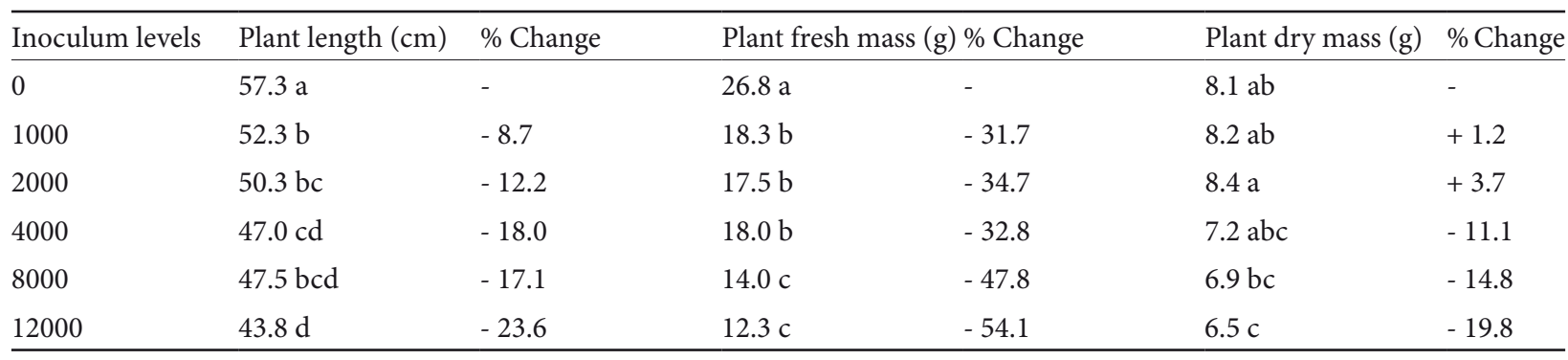

Means followed by the same letter(s) within a column in each block are not significantly different $(p \leq 0.05)$ according to Duncans' multiple range test. 
Table 2: Effect of different levels of $H$. indicus inocula on NPK contents of papaya plants.

\begin{tabular}{|c|c|c|c|c|c|c|}
\hline \multirow[b]{2}{*}{$\begin{array}{l}\text { Inoculum level } \\
\text { (infective } \\
\text { stages/pot) }\end{array}$} & \multicolumn{6}{|l|}{ Plant analysis } \\
\hline & $\begin{array}{l}\mathrm{N} \\
\left(\mathrm{g}, 100 \mathrm{~g}^{-1} \text { dry }\right. \\
\text { mass) }\end{array}$ & $\begin{array}{l}\% \\
\text { Change }\end{array}$ & $\begin{array}{l}\mathrm{P} \\
\left(\mathrm{g} 100 \mathrm{~g}^{-1} \text { dry }\right. \\
\text { mass }\end{array}$ & $\begin{array}{l}\% \\
\text { Change }\end{array}$ & $\begin{array}{l}\mathrm{K} \\
\text { (g } 100 \mathrm{~g}^{-1} \text { dry } \\
\text { mass) }\end{array}$ & $\begin{array}{l}\% \\
\text { Change }\end{array}$ \\
\hline 0 & $1.6 \mathrm{a}$ & - & $2.9 \mathrm{c}$ & - & $3.5 \mathrm{a}$ & - \\
\hline 1000 & $1.3 \mathrm{~b}$ & -18.8 & $4.4 \mathrm{ab}$ & +51.7 & $3.6 \mathrm{a}$ & +2.9 \\
\hline 2000 & $1.4 \mathrm{ab}$ & -12.5 & $3.5 \mathrm{bc}$ & +20.7 & $3.0 \mathrm{ab}$ & -14.3 \\
\hline 4000 & $1.5 \mathrm{ab}$ & -6.3 & $4.7 \mathrm{a}$ & +62.1 & $2.4 \mathrm{~b}$ & -31.4 \\
\hline 8000 & $1.6 \mathrm{a}$ & 0.0 & $4.4 \mathrm{ab}$ & +51.7 & $3.0 \mathrm{ab}$ & -14.3 \\
\hline 12000 & $1.6 \mathrm{a}$ & 0.0 & $4.7 \mathrm{a}$ & +62.1 & $2.6 \mathrm{ab}$ & -25.7 \\
\hline
\end{tabular}

Means followed by the same letter(s) within a column in each block are not significantly different $(p \leq 0.05)$ according to Duncans' multiple range test.

Table 3: Multiplication of $H$. indicus on papaya as affected by different inoculum levels

\begin{tabular}{lllll}
\hline & Nematode counts & & \\
\cline { 2 - 5 } Inoculum levels & On root & In soil & Total & Pf/Pi \\
\hline 1000 & $206 \mathrm{~b}$ & $23925 \mathrm{a}$ & 24131 & $24.2 \mathrm{a}$ \\
2000 & $269 \mathrm{~b}$ & $22290 \mathrm{ab}$ & 22559 & $11.3 \mathrm{~b}$ \\
4000 & $206 \mathrm{~b}$ & $22640 \mathrm{ab}$ & 22846 & $5.7 \mathrm{c}$ \\
8000 & $598 \mathrm{a}$ & $19450 \mathrm{~b}$ & 20048 & $2.5 \mathrm{~d}$ \\
12000 & $294 \mathrm{~b}$ & $21485 \mathrm{ab}$ & 21779 & $1.8 \mathrm{~d}$ \\
\hline
\end{tabular}

Means followed by the same letter(s) within a column in each block are not significantly different $(p \leq 0.05)$ according to Duncans' multiple range test.

Table 4: Effects of different bio-organic materials on papaya growth infected with $H$. indicus

\begin{tabular}{|c|c|c|c|c|c|c|c|}
\hline Treatment & $\begin{array}{l}\text { Dose/plant } \\
\text { (one month } \\
\text { interval) }\end{array}$ & $\begin{array}{l}\text { Plant length } \\
(\mathrm{cm})\end{array}$ & $\begin{array}{l}\% \\
\text { Change }\end{array}$ & $\begin{array}{l}\text { Plant fresh } \\
\text { mass }(\mathrm{g})\end{array}$ & $\begin{array}{l}\% \\
\text { Change }\end{array}$ & $\begin{array}{l}\text { Plant dry } \\
\text { mass (g) }\end{array}$ & $\begin{array}{l}\% \\
\text { Change }\end{array}$ \\
\hline Bio Tonic ${ }^{\circ}$ & $5 g+5 g$ & $53.3 \mathrm{a}$ & +19.8 & $18.3 \mathrm{c}$ & +39.7 & $7.1 \mathrm{ab}$ & +9.2 \\
\hline Hundz Soil ${ }^{\circ}$ & $5 g+5 g$ & $53.8 \mathrm{a}$ & +20.9 & $21.9 \mathrm{~b}$ & +67.2 & $7.1 \mathrm{ab}$ & +9.2 \\
\hline Nemakey-N"' & $5 \mathrm{ml}+5 \mathrm{ml}$ & $58.4 \mathrm{a}$ & +31.2 & $28.2 \mathrm{a}$ & +115.3 & $8.8 \mathrm{a}$ & +35.4 \\
\hline Nemastop ${ }^{\circ}$ & $5 \mathrm{ml}+5 \mathrm{ml}$ & $47.0 \mathrm{~b}$ & +5.6 & $14.0 \mathrm{~d}$ & +6.9 & $7.2 \mathrm{ab}$ & +10.8 \\
\hline Nubtea ${ }^{\circ}$ & $5 g+5 g$ & $52.5 \mathrm{a}$ & +18.0 & $26.3 \mathrm{a}$ & +100.8 & $7.8 \mathrm{a}$ & +20.0 \\
\hline Nematode only & - & $43.0 \mathrm{~b}$ & -3.4 & $12.5 \mathrm{~d}$ & -4.6 & $6.1 \mathrm{~b}$ & -6.2 \\
\hline Healthy & - & $44.5 \mathrm{~b}$ & - & $13.1 \mathrm{~d}$ & - & $6.5 \mathrm{ab}$ & - \\
\hline
\end{tabular}

Means followed by the same letter(s) within a column in each block are not significantly different $(p \leq 0.05)$ according to Duncans' multiple range test.

up. That reduction was proportional with repeating dose which outmatched the inoculated check. Differences in nematode suppression were noticeable among treatments. Nemakey- $\mathrm{N}^{\mathrm{m}}$ performed the highest smashing reductions in nematode criteria $(78.3 \%)$ and exhibited the sharpest inhibition in nematode build up followed by Hundz Soil', Nemastop and Bio Tonic treatments. Sig- nificant but less persuasive reductions in nematode criteria were achieved by Nubtea treatment.

\section{DISCUSSION}

Reduction in plant growth parameters of papaya has 
Table 5: Effect of bio-organic materials on NPK contents of papaya plants infected with $H$. indicus

\begin{tabular}{|c|c|c|c|c|c|c|c|}
\hline \multirow[b]{2}{*}{ Treatment } & \multirow[b]{2}{*}{$\begin{array}{l}\text { Dose/plant } \\
\text { (one month } \\
\text { interval) }\end{array}$} & \multicolumn{6}{|l|}{ Plant analysis } \\
\hline & & $\begin{array}{l}\mathrm{N} \\
\left(\mathrm{g} 100 \mathrm{~g}^{-1} \mathrm{dry}\right. \\
\text { mass) }\end{array}$ & $\begin{array}{l}\% \\
\text { Change }\end{array}$ & $\begin{array}{l}\mathrm{P} \\
\text { (g } 100 \mathrm{~g}^{-1} \mathrm{dry} \\
\text { mass) }\end{array}$ & $\begin{array}{l}\% \\
\text { Change }\end{array}$ & $\begin{array}{l}\mathrm{K} \\
\text { (g } 100 \mathrm{~g}^{-1} \mathrm{dry} \\
\text { mass) }\end{array}$ & $\begin{array}{l}\% \\
\text { Change }\end{array}$ \\
\hline Bio Tonic & $5 g+5 g$ & $1.4 \mathrm{c}$ & -6.7 & $3.6 \mathrm{~b}$ & -23.4 & $3.8 \mathrm{a}$ & +58.3 \\
\hline Hundz Soil ${ }^{\circ}$ & $5 g+5 g$ & $1.6 \mathrm{bc}$ & +6.7 & $3.7 \mathrm{~b}$ & -21.3 & $3.9 \mathrm{a}$ & +62.5 \\
\hline Nemakey- ${ }^{\mathrm{m}}$ & $5 \mathrm{ml}+5 \mathrm{ml}$ & $1.7 \mathrm{ab}$ & +13.3 & $3.6 \mathrm{~b}$ & -23.4 & $2.8 \mathrm{c}$ & +16.7 \\
\hline Nemastop & $5 \mathrm{ml}+5 \mathrm{ml}$ & $1.5 \mathrm{bc}$ & 0.0 & $3.7 \mathrm{~b}$ & -21.3 & $2.6 \mathrm{~cd}$ & +8.3 \\
\hline Nubtea & $5 g+5 g$ & $1.9 \mathrm{a}$ & +26.7 & $2.7 \mathrm{c}$ & -42.6 & $3.1 \mathrm{~b}$ & +29.2 \\
\hline Nematode only & - & $1.5 \mathrm{bc}$ & - & $4.7 \mathrm{a}$ & - & $2.4 \mathrm{~d}$ & - \\
\hline
\end{tabular}

Means followed by the same letter(s) within a column in each block are not significantly different $(p \leq 0.05)$ according to Duncans' multiple range test.

Table 6: Multiplication of $H$. indicus on papaya as affected by different bio-organic materials

\begin{tabular}{|c|c|c|c|c|c|c|}
\hline \multirow[b]{2}{*}{ Treatment } & \multirow{2}{*}{$\begin{array}{l}\text { Dose / plant } \\
\text { (one month in- } \\
\text { terval) }\end{array}$} & \multicolumn{5}{|c|}{ Nematode counts } \\
\hline & & On root & In soil & Total & $\mathrm{Pf} / \mathrm{Pi}$ & $\%$ Efficiency ${ }^{*}$ \\
\hline Bio Tonic ${ }^{\circ}$ & $5 g+5 g$ & $170 \mathrm{c}$ & $10335 \mathrm{c}$ & $10505 \mathrm{c}$ & $2.6 \mathrm{c}$ & 62.3 \\
\hline Hundz Soil ${ }^{\circ}$ & $5 g+5 g$ & $121 \mathrm{~d}$ & $6810 \mathrm{~d}$ & $6931 \mathrm{~d}$ & $1.7 \mathrm{~d}$ & 75.4 \\
\hline Nemakey- ${ }^{\mathrm{w}}$ & $5 \mathrm{ml}+5 \mathrm{ml}$ & $96 \mathrm{e}$ & $5730 \mathrm{e}$ & $5826 \mathrm{e}$ & $1.5 \mathrm{e}$ & 78.3 \\
\hline Nemastop & $5 \mathrm{ml}+5 \mathrm{ml}$ & $114 \mathrm{de}$ & $6780 \mathrm{~d}$ & $6894 \mathrm{~d}$ & $1.7 \mathrm{~d}$ & 75.4 \\
\hline Nubtea & $5 g+5 g$ & $204 b$ & $21615 b$ & $21819 b$ & $5.5 \mathrm{~b}$ & 20.3 \\
\hline Nematode only & - & $360 \mathrm{a}$ & $27168 \mathrm{a}$ & $27528 \mathrm{a}$ & $6.9 \mathrm{a}$ & - \\
\hline
\end{tabular}

Means followed by the same letter(s) within a column in each block are not significantly different $(p \leq 0.05)$ according to Duncans' multiple range test.

$* \%$ Efficiency $=(($ Nematode build up in control - Nematode build up in treatment $) /$ Nematode build up in control $) \times 100$.

been governed by inoculation level of nematode which was at and above 2000 infective stages/plant. However, the significant reduction in plants growth parameters was noticed at and above 4000 inoculum levels. Our results are in agreement with those of Firoza and Maqbool (1995) who studied the effect of different population densities of $H$. dihystera (Cobb, 1893; Sher, 1961) on growth of brinjal, tomato and wheat reporting 4000 nematodes $\mathrm{kg}^{-1}$ soil as damaging threshold level.

Rate of nematode multiplication has considerably affected by the inoculation level. By increasing inoculum levels of the nematode, corresponding decrease in rate of multiplication could occur. This may be due to shortage of food or competition for suitable feeding sites (Sartaj et al, 1999; Kumar and Singh, 2007 and Rashid and Azad, 2013). Moreover, our results are not in agreement with those of Rao and Swarup (1974), Sartaj et al. (1999) and Kumar and Singh (2007) who reported that the damaging threshold level varied between 500 to 5000 inoculum level on different crops. This variation may be possibly due to either different crop plants used or change in experimental conditions.

Practically the tested organic materials could manage $H$. indicus and improve papaya growth. The literature concerning suppression of phytonematode densities by organic amendments is replete with both promising and inconsistent results (Al-Sayed et al., 2007; Kesba and AlShalaby, 2008; Siddiqui et al., 2009; Farahat et al., 2012 and Kesba et al., 2013). Additions of organic materials to soils have been known to improve crop productivity. Moreover, such materials have beneficial effects on soil nutrients (as substrate for microorganisms), soil physical conditions (water retention, cation exchange capacity and soil aggregation), soil biological activity and crop performance (McConnell et al., 1993; Abo-Elyousr et al., 2010; Shankar et al., 2011). These changes in soil chemical and physical properties may induce plant responses that have increased their tolerance to nematodes, as suggested by McSorley and Gallaher (1995). The efficacy of organic amendments against the plant parasitic nematodes depends on different factors, including the nema- 
tode species (McSorley and Gallaher, 1996), the chemical composition of the amendments and the ratio of C:N (Rashad et al., 2011)

The obtained results revealed that most inoculation levels reduced plant contents of $\mathrm{N}$ and $\mathrm{K}$ but increased $\mathrm{P}$. Similar results were obtained on different nematode species by Singh and Chaudhury (1974) on tomato and by Kesba and Al-Sayed (2005) on grape and Kesba (2011) on pepper, whilst contradictory results were reported by Oteifa and El-Gindi (1962) on tomato and Shafee and Jenkins (1963) on pepper. Regarding the NPK content changes, results of the present study indicated that most materials increased plant contents of $\mathrm{N} \& \mathrm{~K}$. The type and dose of the materials reflected the variations in the content of inorganic elements in the treated plants. Incidentally, increase in $\mathrm{N}$ and $\mathrm{P}$ coincides with the increase in amino acids and nucleic acids, and it is quite likely that some of these inorganic substances are incorporated into various organic compounds, while $\mathrm{K}$ may be characteristic of growing tissues (Roy, 1981 and Kesba et al., 2012 \& 2013). Also, contradiction may be due to many factors e.g. used doses, origin of the material, plant variety, susceptibility, nematode species, inoculum density, assayed plant part and time of harvest (Tayal and Agrawal, 1982, Al-Sayed et al., 2007 \& 2016, Farahat et al., 2012 and Kesba, et al., 2013).

\section{REFERENCES}

Abo-Elyousr, K.A., Khan, Z., El-Morsi, A.M. and Abedel-Moneim, M.F. (2010). Evaluation of plant extracts and Pseudomonas spp. for control of root-knot nematode, Meloidogyne incognita on tomato. Nematropica, 40(2), 289-299.

Ahmad, F. and Siddiqui, M.D. (2009). Management of rootknot nematode Meloidogyne incognita in tomato. Pakistan Journal of Nematology, 27(2), 369-373.

Al-Sayed, A.A., Abdel-Rahman, A.A. and Kesba, H.H. (2016). Ring and spiral nematodes reproduction and Turfgrass growth as influenced by heavy metals treatments. Annals of Plant Protection Sciences, 24(2), 411-417.

Al-Sayed, A.A., Kheir, A.M., El-Naggar, H.I. and Kesba, H.H. (2007). Organic management of Meloidogyne incognita on grapes in relation to host biochemistry. International Journal of Agricultural Research, 2(9), 776-785. https://doi. org/10.3923/ijar.2007.776.785

Anon. (1990). Official methods of analysis. 15th edition. Washington, DC, USA, Association of Official Analytical Chemists, $684 \mathrm{pp}$.

Farahat, A.A., Al-Sayed, A.A. and Mahfoud, N.A. (2010). Compost and other organic and inorganic fertilizers in the scope of the root-knot nematode reproduction and control of $\mathrm{Me}$ loidogyne incognita infecting tomato. Egyptian Journal of Agronematology, 9(1), 18-29.

Farahat, A.A., Al-Sayed, A.A.; El-Beltagi, H.S. and Mahfoud, N.A. (2012). Impact of organic and inorganic fertilizers on nematode reproduction and biochemical alterations on tomato. Notulae Scientia Biologicae, 4(1), 48-55. https://doi. org/10.15835/nsb416660

Firoza, K. and Maqbool, M.A. (1995). Numerical threshold for infection of the spiral nematode, Helicotylenchus dihystera (Cobb, 1893) Sher, 1961 on Brinjal, tomato and wheat. Pakstan Journal of Nematology, 13(2), 93-97.

Hooper, D.J., Hallmann, J. and Subbotin, S.A. (2005). Methods for extraction, processing and detection of plant and soil nematodes. In: Luc, M., Sikora, R.A. and Bridge, J. (Eds). Plant parasitic nematodes in subtropical and tropical agriculture. Wallingford, UK, CABI Publishing, pp. 53-86. https:// doi.org/10.1079/9780851997278.0053

Jain, R.K. (1981). Pathogenicity of Helicotylenchus dihystera to Cenchrus ciliaris. Indian Journal of Nematology, 10(2), 236239.

Kesba, H.H. (2010). Biochemical alterations in grape infected with three phytonematode species with emphasis on rootknot nematode control. Egyptian Journal of Agronematology, 9(2), 116-131.

Kesba, H.H. (2011). Pathogenicity of Meloidogyne incognita on pepper and impact of some control measures. International Journal of Nematology, 21(2), 203-209.

Kesba, H.H. and Al-Sayed, A.A. (2005). Interactions of three species of plant-parasitic nematodes with arbuscular mycorrhizal fungus, Glomus macrocarpus, and their effect on grape biochemistry. Nematology, 7(6), 945-952. https://doi. org/10.1163/156854105776186406

Kesba, H.H., Al-Sayed, A.A. and Farahat, A.A. (2012). Controlling Meloidogyne incognita and Rotylenchulus reniformis infecting papaya. Egyptian Journal of Agronematology, 11(2), 354-371.

Kesba, H.H., Al-Shalaby, Mona, E. (2008). Survival and reproduction of Meloidogyne incognita on tomato as affected by humic acid. Nematology, 10(2), 243-249. https://doi. org/10.1163/156854108783476304

Kesba, H.H., El-Helaly, M.A., Abdel Ghanny, S. and Suloma, A. (2013). Potentials of aquaculture effluents on nematode management: 1- effect of tilapia effluents on two nematode species and cowpea growth. Journal of Animal and Plant Sciences, 23(1), 281-289.

Khan, A., Sayed, M. and Shaukat, S.S. (2007). Nematodes associated with papaya in Sindh (Pakistan). Sarhad Journal of Agriculture, 23(1), 145-147.

Khanna, A.S. and Jyot, J. (2002). Pathogenic potential of Helicotylenchus variuudatus and Paratylenchus curwtatus on Dunthus caryophillus. Nematologia_Mediterranea, 30, 201202.

Kheir, A.M., Al-Sayed, A.A. and Saeed, M.R. (2009). Suppressive effects of inorganic fertilizers on $M$. incognita infecting soybean. Egyptian Journal of Agronematology, 7(1), 9-19.

Kumar, D. and Singh, V.S. (2007). Pathogenicity of spiral nematode, $H$. indicus and effect of chlorophyll content of maize. Indian Journal of Nematology, 37, 101-102.

MALR (2014). Bulletin of economic affairs sector, Egyptian Ministry of Agriculture and Land Reclamation, Egypt.

Marais, M. (2001). A monograph of the genus Helicotylenchus Steiner, 1945 (Nemata: Hoplolaimidae). Ph.D. Dissertation, University of Stellenbosch, Stellenbosch, South Africa. 
McConnell, J.S., Baker, W.H., Miller, D.M., Frizzell, B.S. and Varvil, J.J. (1993). Nitrogen fertilization of cotton cultivars of differing maturity. Agronomy Journal, 85, 1151-1156. https://doi.org/10.2134/agronj1993.00021962008500060011x

McSorley, R. and Gallaher, R.N. (1995). Effectof yard waste compost on plant-parasitic nematode densities in vegetable crops. Supplement to the Journal of Nematology, 27(4S), 545-549.

McSorley, R. and Gallaher, R.N. (1996). Effect of yard waste compost on nematode densities and maize yield. Supplement to the Journal of Nematology, 28(4S), 655-660.

Moens, T., Araya, M., Swennen, R. and De Waele, D. (2006). Reproduction and pathogenicity of Helicotylenchus multicinctus, Meloidogyne incognita and Pratylenchus coffeae, and their interaction with Radopholus similis on Musa. Nematology, 8, 45-58. https://doi.org/10.1163/156854106776179999

MSTAT Version 4 (1987). Software program for the design and analysis of agronomic research experiments. Michigan, USA, Michigan State University.

Oteifa, B.A. and El-Gindi, D.M. (1962). Influence of parasitic duration of Meloidogyne javanica (Treub) on host nutrient uptake. Nematologica, 8, 216-220. https://doi. org/10.1163/187529262X00459

Rao, V.R. and Swarup, G. (1974). Pathogenicity of spiral nematode, Helicotylenchus dihystera to sugarcane. Indian Journal of Nematology, 4,160-166.

Rashad, F.M., Kesba, H.H., Saleh, W.D. and Moselhy, M.M. (2011). Impact of rice straw composts on microbial population, plant growth, nutrient uptake and root-knot nematode under greenhouse conditions. African Journal of Agricultural Research, 6(5), 1188-1203.

Rashid, A. and Azad, S. A. (2013). Studies on the pathogenicity of Helicotylenchus dihystera on Celosia cristata. Indian Journal of Scientific Research, 4(1), 153-154.

Roy, T.K. (1981). Biochemical aspects of host-parasite relationships in plant parasitic nematodes. Proceedings of the Indian National Science Academy, 47(6), 919-936.

Sartaj, A., Tiyagi, N.V. and Alam, M.M. (1999). Inoculum potential of spiral nematodes, Helicotylenchus indicus in relation to growth of chickpea. Annals of Plant Protection Sciences, 7,212-251.

Schreck Reis, C., Freitas, H. and van der Putten, W.H. (2008). Responses of root-feeding nematodes (Helicotylenchus spp.) to local and non-local populations of the host plant Ammophila arenaria. Applied Soil Ecology, 39, 245-253. https://doi.org/10.1016/j.apsoil.2008.01.003

Shafiee, M.F. and Jenkins, W.R. (1963). Host-parasitic of Capsicum frutescens and Pratylenchus penetrans, Meloidogyne incognita acrita and Meloidogyne hapla. Phytopathology, 53, 325-328.
Shankar, T.; Pavaraj, M.; Umamaheswari, K.; Prabhu, D. and Baskaran, S. (2011). Effect of Pseudomonas aeruginosa on the root-knot nematode, Meladogyne incognita infecting tomato, Lycoperiscum esculentum. Academic Journal of Entomology, 4(3), 114-117.

Siddiqi, M.R. (1963). Two new species of the genus, Helicotylenchus Steiner, 1945 (Nematoda: Hoplolaiminae). Zeitschrift für Parasitenkunde, 23, 239-244. https://doi.org/10.1007/ BF00259374

Siddiqui, Z.A., Qureshi, A. and Akhtar, M.S. (2009). Biocontrol of root-knot nematode, Meloidogyne incognita by Pseudomonas and Bacillus isolates on Pisum sativum. Archives of Phytopathology and Plant Protection, 42(12), 1154-1164. https://doi.org/10.1080/03235400701650890

Singh, B. and Chaudhury, B. (1974). Screening tomato cultivars for resistance to Meloidogyne species. Tropical Pest Management, 20, 319-322. https://doi. org/10.1080/09670877409411857

Sinha, A.K. and Neog, P.P. (2003). Effect of different levels of NPK fertilizers against citrus nematode (Tylenchulus semipenetrans) on Khasi mandarin. Indian Journal of Nematology, 33, 61- 62 .

Tayal, M.S. and Agrawal, M.L. (1982). Biochemical alterations in galls induced by Meloidogyne incognita: some hydrolyzing enzymes and related chemical metabolites. Indian Journal of Nematology, 12, 379-382.

Teixeira da Silva, J.A., Rashid, Z., Nhut, D.T., Sivakumar, D., Gera, A., Souza Jr., M.T. and Tennant, P.F. (2007). Papaya (Carica papaya L.) biology and biotechnology. Tree and Forestry Science and Biotechnology, 1(1), 47-73.

Uzma, I., Nasira, K., Firoza, K. and Shahina, F. (2015). Review of the genus Helicotylenchus Steiner, 1945 (Nematoda: Hoplolaimidae) with updated diagnostic compendium. Pakistan Journal of Nematology, 33(2), 115-160. https://doi. org/10.18681/2015.v33.i02.p01201507310001

Willers, P. and Grech, N.M. (1986). Pathogenicity of the spiral nematode, Helicotylenchus dihystera to Guava. Plant Disease, 70,352. https://doi.org/10.1094/PD-70-352b

Zahid, M.I., Gurr, G.M., Hodda, M., Nikandrow, A. and Fulkerson, W.J. (2002). Orientation, reproduction and effect of spiral nematode (Helicotylenchus dihystera) on growth of white clover (cv. Haifa). Australasian Plant Pathology, 31(1), 55-56. https://doi.org/10.1071/AP01052

Zhang, S. and Zhang, X. (2009). Effects of two composted plant pesticide residues incorporated with Trichoderma viride on root-knot nematode in ballon flower. Agricultural Sciences in China, 8, 447-454. https://doi.org/10.1016/S16712927(08)60231-X 